\title{
Teratological effects of 2,4-dinitrophenol, 'produced water' and naphthalene on embryos of the inland silverside Menidia beryllina*
}

\author{
D. P. Middaugh, M. J. Hemmer, E. M. Lores \\ US Environmental Protection Agency, Gulf Breeze Environmental Research Laboratory, Sabine Island, Gulf Breeze, \\ Florida 32561, USA
}

\begin{abstract}
Embryos of the inland silverside Menidia beryllina were exposed to 3 teratogens: (1) 2,4dinitrophenol, (2,4-DNP), (2) 'produced water' (PW), and (3) naphthalene (NPH). Tests were conducted by placing single embryos in glass tissue culture tubes containing $6 \mathrm{ml}$ of saline exposure media. Twenty tubes were used for each exposure concentration and for controls. A severity-index based upon craniofacial, cardiovascular, and skeletal terata was used to rank responses each day. The compounds tested caused teratogenic expressions in embryos and larvae exposed from the 2- to 4-cell and blastula stage through 7 to $8 \mathrm{~d}$ post-fertilization. However, combined survival in control embryos and larvae, and those exposed to respective teratogens, were not significantly different in 5 of 6 tests, except the 2- to 4-cell embryos exposed to 2,4-DNP. There was a marked increase in the relative frequency of terata with increasing nominal exposure concentrations of each compound. Post-hoc comparison of mean rank scores for severity of expression between control and exposed individuals revealed statistically

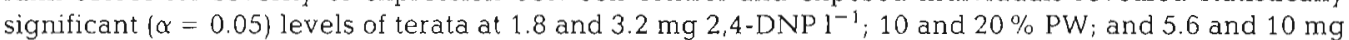
$\mathrm{NPH} 1^{-1}$
\end{abstract}

\section{INTRODUCTION}

The effect of the pesticide and fungicide 2,4-dinitrophenol $(2,4$-DNP) on developing fish embryos has been studied in several species including medaka Oryzias latipes (Waterman 1939), Atlantic herring Clupea harengus harengus (Rosenthal \& Stelzer 1970, Stelzer et al. 1971), and trout Salmo irideus (Devillers \& Chanconie 1972). Concentrations of 2,4-DNP ranging from 1 to $4 \mathrm{mg}$ $1^{-1}$ caused severe malformations, such as anophthalmy, symmetrical and unilateral microphthalmy, curled bodies, and dedifferentiation of embryos.

'Produced water' (PW) is usually a saline formation water, that may be a by-product of oil and gas production. This water is separated from crude oil products, and is generally discharged to surface waters. It may contain aliphatic and aromatic compounds, sulfur, and heavy metals, among other components (Middleditch 1981, 1984). Many of the components found in our sample of PW are also present in the water-soluble fraction (WSF) of crude oil.

\footnotetext{
- Contribution No, 613, Gulf Breeze Environmental Research. Laboratory
}

The WSF of crude oil has produced terata in fish embryos and larvae. Exposure of Pacific herring Clupea harengus pallast embryos to the WSF of Prudhoe Bay crude oil at an initial concentration of 0.68 mg $1^{-1}$ (major components: naphthalene $17 \%$, methylnaphathalene $13 \%$, and dimethylnaphthalene 5\%) resulted in gross abnormalities including flexures in the body that reduced or prevented locomotion. Defects in mouth structure were also noted (Smith \& Cameron 1979). In a follow-up study, electron microscopy revealed abnormal inter-and intracellular spaces in brain and muscle tissue of newly hatched larvae (Cameron \& Smith 1980).

Because naphthalenes are usually a major constituent in the WSF of crude oil (and also PW), several studies have examined the response of fish embryos to these compounds. Reductions in length at hatching were observed in larval killifish Fundulus heteroclitus exposed to approximately $1.5 \mathrm{mg} \mathrm{l}^{-1}$ total aqueous hydrocarbons $\left(0.4 \mathrm{mg}\right.$ naphthalene $\left.\mathrm{1}^{-1}\right)$. The instantaneous uptake rate of ${ }^{14} \mathrm{C}$-naphthalene was highest in 2 -d-old embryos and decreased in older embryos (Sharp et al. 1979). Moreover, exposure of embryos of 6 species of marine fish to 2 -methylnaphthalene for $4 \mathrm{~d}$ 
revealed that sensitivity apparently was a function of chorion thickness. Initial concentrations of 1 to $6 \mathrm{ppm}$ resulted in irregular cleavage patterns consisting of retarded cell divisions and divisions into cells of different sizes. Opaque spots were also observed in the blastodisc, which often was irregular in shape. Abnormalities were observed in at least $50 \%$ of the embryos of 5 species and in about $15 \%$ of plaice Pleuronectes platessa embryos. The latter have a relatively thick chorion (Stene \& Lonning 1984).

Our study determined the feasibility of using glass tissue culture tubes for exposing Menidia beryllina embryos to teratogens. This method of exposure requires the use of a small volume of toxicant solution and reduces observer risk because tubes are tightly sealed for the duration of the test. Tests were begun with 2- to 4-cell and blastula stage embryos (Lagler et al. 1977). Three teratogens currently being introduced into the environment were used. They included: (1) 2,4-dinitrophenol (2,4-DNP), a known teratogen used as an insecticide, acaricide, and fungicide (Farm Chemicals Handbook 1986), (2) 'produced water' (PW), a saline by-product of crude oil production that is discharged to the environment and which may contain substantial quantities of hydrocarbons (Middleditch 1981, 1984), and (3) naphthalene (NPH), an insecticidal fumigant that was also a component of the produced water' tested in this study.

\section{MATERIALS AND METHODS}

Embryos for testing. Naturally spawned and fertilized embryos of the inland silverside Menidia beryllina were obtained from a population of adults collected from Lake Chicot, Arkansas, USA, and maintained in the laboratory. The laboratory spawning system was described by Middaugh \& Hemmer (1984) and Middaugh et al. (1986).

In brief, 60 individuals (sex ratio 1:1) were placed in each of a pair of $1.3 \mathrm{~m}$ diameter brood tanks in a recirculating spawning system. The system was filled with aged ( 2 wk) tap water. Instant Ocean ${ }^{(B)}$ Sea Salt* was added to provide a measured salinity of 2 ppt (\%o). Water was pumped from a reservoir-filter system through the brood tanks, producing a surface current velocity of 6 to $8 \mathrm{~cm} \mathrm{~s}^{-1}$. A gravity-flow drain returned water to the reservoir via a filter unit containing layers (surface to bottom) of aquarium filter fiber, activated charcoal, crushed oyster shell, and coarse pea gravel. 'Cool-white' fluorescent lamps provided 6.5 to $7.5 \mu \mathrm{E}$ $\mathrm{m}^{-2} \mathrm{~s}^{-1}$ light intensity. The photoperiod was 13L:11D.

- Mention of commercial products does not imply endorsement by the US Environmental Protection Agency
Light-tight curtains shielded the tanks from outside disturbance. Adults were fed Tetramin ${ }^{*}$ (Standard Mix-Large flake) food 4 times daily A spawning substrate made of polyester aquarium filter fiber, $15 \mathrm{~cm}$ long $\times 10 \mathrm{~cm}$ wide $\times 10 \mathrm{~cm}$ thick, was suspended just below the surface of the water and in contact with the side of the brood tank. Fertilized embryos in the 2- to 4 cell or blastula stage were harvested from the spawning substrate between 08:00 and 11:00 h on days when tests were started.

Exposure procedures. Seawater from Santa Rosa Sound, Florida, USA, used in all tests, was treated by pre-filtration through a $20 \mu \mathrm{m}$ polypropylene filter. It was then passed through a $6 \mu \mathrm{m}$ vacuum filtration unit, diluted to $5 \%$ salinity with deionized water, and autorlaved. For tests with PW. an appropriate salinity ranging from 0.35 to $7 \%$ was obtained by diluting with deionized water.

2,4-DNP. A stock solution of $1 \mathrm{mg} \mathrm{2,4-DNP} \mathrm{ml}^{-1}$ was prepared by dissolving the analytical grade chemical (EPA Repository, Research Triangle Park, North Carolina, USA) in deionized, glass-distilled water. Appropriate aliquots of this stock solution were added to $250 \mathrm{ml}$ volumetric flasks containing sterile saline media at $5 \%$ salinity to yield nominal concentrations of $0.56,1.0,1.8$, and $3.2 \mathrm{mg} \mathrm{2,4-DNP} \mathrm{l}^{-1}$.

Six $\mathrm{ml}$ of respective stock solutions (or clean $5 \%$ saline water for controls) was added to each of 20 borosilicate glass tissue culture tubes $16 \times 93 \mathrm{~mm}$ (window size $11 \times 55 \mathrm{~mm}$ ). Tubes, including 20 controls, were then randomized and a single 2- to 4-cell, or blastula stage embryo was added to each. A teflonlined screw cap was used to seal each tube. Thus, 20 tubes were used for each exposure concentration and for each control in respective tests with 2,4-DNP, PW and NPH. Tubes, with an airspace of $7 \mathrm{ml}$, were placed in racks and stored in a horizontal position in an incubator at $25 \pm 1{ }^{\circ} \mathrm{C}$ with a 14L:10D photoperiod. Cool-white fluorescent lamps provided $17.5 \mu \mathrm{E} \mathrm{m}^{-2} \mathrm{~s}^{-1}$ illumination during the light phase. Concentrations of 2,4-DNP in exposure tubes were measured at the end of the 7 to $8 \mathrm{~d}$ tests.

Samples were analysed by direct injection of exposure solutions into a Waters High Pressure Liquid Chromatograph with a CL-4A (BioAnalytical System, West Lafayette, Indiana, USA) electrochemical detector operated in the reductive mode. A $25 \mathrm{~cm} \mathrm{C}-18$ column with a mobile phase of $60 \%$ methanol, $40 \%$ $0.05 \mathrm{M}, \mathrm{pH} 2.5$ phosphate buffer was used for the separation. The flow rate was $1.0 \mathrm{ml} \mathrm{min} \mathrm{m}^{-1}$ at ambient temperature. Samples were quantified using peak height measurement; the detection limit was $0.03 \mathrm{mg}$ $1^{-1}$.

At the end of each test, 5 tubes from each treatment were checked for oxygen saturation by uncapping the 
tube and slowly withdrawing a sample into a $1.0 \mathrm{ml}$ syringe. Individual samples were injected into a Radiometer BMS 3 MK2 Blood Micro System with attached PHM 71 MK2 Acid-Base Analyser and a direct measurement recorded for partial pressure of oxygen which was converted to dissolved oxygen ( $\mathrm{DO} ; \mathrm{ml}^{-1}$ ). The $\mathrm{pH}$ of test solutions was also measured in 5 additional tubes from each treatment using an Orion SA $520 \mathrm{pH}$ meter

'Produced water'. The PW sample used in this study was a saline effluent discharged from a centralized collection pit for producing inshore oil wells. The PW was collected directly into a sterile $20 \mathrm{l}$ glass carboy until it was filled to capacity (no air space), and sealed with a teflon-lined cap. The carboy was placed in a large insulated cooler containing crushed ice and returned to the laboratory. Thereafter, the sample was stored at $4{ }^{\circ} \mathrm{C}$ in darkness until used.

Prior to testing, the original sample was stirred for 3 min using an electric lab stirrer and a subsample removed by decanting into a sterile $1 \mathrm{l}$ volumetric flask. The subsample, salinity $35 \%$, was diluted in sterile 11 glass bottles, using deionized, glass-distilled water to yield final nominal concentrations of 1, 5, 10 and $20 \%$ PW. Twenty embryos in individual tissue culture tubes were exposed to each concentration of PW. Salinity in the diluted samples ranged from $0.35 \%$ for the $1 \%$ concentration of PW to $7 \%$ for the $20 \%$ concentration. Accordingly, 2 groups of controls ( $N=20$ each) were maintained in tests initiated with 2 - to 4 -cell and blastula stage embryos. One control group was at $0.35 \%$, another at $7 \%$ salinity.

Chemical analyses were not conducted at the end of the 7 to 8 d exposures. However, a scan of PW for 319 substances; non-volatile and volatile organics, metals, and other components was conducted 2 wk after the original sample was collected. Analytical procedures are summarized in US EPA 1987. Methods for measurement of DO and $\mathrm{pH}$ in each test with $\mathrm{PW}$ were identical to those described for 2,4-DNP.

Naphthalene. A stock solution of $1 \mathrm{mg} \mathrm{NPH} \mathrm{ml}^{-1}$ was prepared by dissolving analytical grade chemical (Applied Science Corp., Deerfield, Illinois, USA) in deionized, glass-distilled water. Appropriate aliquots of this stock solution were added to $250 \mathrm{ml}$ volumetric flasks containing sterile seawater at $5 \%$ salinity to yield nominal concentrations of $1.8,3.2,5.6$ and $10 \mathrm{mg}$ $\mathrm{NPH} \mathrm{l}^{-1}$. Twenty embryos in individual tissue culture tubes were exposed to each concentration of NPH and 20 control tubes were maintained in respective tests. Concentrations of NPH in exposure tubes were measured at the end of tests.

Solutions containing NPH were analysed by extraction with hexane. The hexane was injected, without concentration, into a gas chromatograph equipped with a $2 \mathrm{~m} \times 2 \mathrm{~mm}, 5 \%$ OV 101 column with a flame ionization detector. The oven was maintained isothermal at $110^{\circ} \mathrm{C}$. Quantitation was accomplished with a Hewlett-Packard 3357 Lab Automation System; the detection limit was $0.2 \mathrm{mg} \mathrm{l}^{-1}$. Sampling procedures for ambient $\mathrm{DO}$ and $\mathrm{pH}$ at the end of each 7 to $8 \mathrm{~d}$ test were identical to those described for 2,4-DNP.

Utilization of tissue culture tubes allowed us to incubate developing embryos in a sealed system for the duration of each test. This approach was desirable because it essentially eliminated potential exposure of observers to toxicants of unknown hazard. Moreover, a test with 4 exposure concentrations resulted in less than $500 \mathrm{ml}$ of toxic waste which had to be disposed of in a responsible manner.

Observations for effect. Individual embryos exposed to each toxicant, and respective controls, were observed daily 7 to $8 \mathrm{~d}$ until death or hatching occurred. A Zeiss Invertoscope D Microscope, equipped for photomicrography, was used to categorize results. Observed terata were scored each day using a numerical 'severity-index' for craniofacial (CR), cardiovascular (CV), and skeletal (SK) defects. Numerical scores for categorical data (Table 1) were based upon classification schemes devised by Weis \& Weis (1977), Weis et al. (1981), and Weis \& Weis (1982) for scoring defects in embryonic mummichogs Fundulus heteroclitus and Atlantic silversides Menidia menidia.

Statistical analysis. Survival data. Upon completion of a test, the combined percentage survival (for embryos and larvae) was calculated for the control(s) and each treatment concentration. Survival data were then arc sine transformed and multiple comparisons, based upon the chi-squared distribution, were made between control(s) and treatments, $\alpha=0.05$ (Marascuilo \& McSweeney 1977).

Total severity-indices. Analysis of teratogenic responses was performed in the following manner: for each tube, CR, CV and SK values (Table 1) were summed to provide a total daily score which could range from 0 for a normally developing embryo to a maximum of 13 for a severely deformed embryo, (i.e. $\mathrm{CR} 3+\mathrm{CV} 5+\mathrm{SK} 5=13$ ). If an embryo died before the end of the test, a value of 14 was assigned to the tube each day from the date of death until test termination. The 7 or 8 daily scores for each tube were then summed to generate a total severity-index for each embryo. It should be pointed out that assignment of a value of 14 to dead embryos on the day of death and for all subsequent days, until the end of each test, enabled us to account for embгуо mortalities without introducing bias into total severity-indices for teratogenicity. By assigning a value of 14 to teratogenexposed and control embryos that died, the uncertainty of causal effect for death was effectively 
Table 1. Menidia beryllina. Synopsis of observed teratological responses in embryos and numerical severity-index for craniofacial (CR), cardiovascular (CV) and skeletal (SK) defects. Adapted in part from Weis \& Weis (1977, 1982), and Weis et ai. (1981)

\begin{tabular}{|c|c|c|}
\hline Craniofacial & Cardiovascular & Skeletal \\
\hline Value Effect & Value Effect & Value Effect \\
\hline 0. None observed & 0. None observed & 0. None observed \\
\hline 1. Slight defect in structure or size & $\begin{array}{l}\text { 1. Slight defect in structure or func- } \\
\text { tion including reduced circulation }\end{array}$ & 1. Slight bend or kink \\
\hline $\begin{array}{l}\text { 2. Moderate defect in structure or } \\
\text { size including synopthalmia }\end{array}$ & $\begin{array}{l}\text { 2. Tube heart, beating with or with- } \\
\text { out circulation }\end{array}$ & $\begin{array}{l}\text { 2. Major bend or kink (greater than } \\
90^{\circ} \text { angle, or more than one bend) }\end{array}$ \\
\hline \multirow[t]{3}{*}{ 3. $\mathrm{s}$} & 3. Tube heart, not beating & 3. Stunted \\
\hline & $\begin{array}{l}\text { 4. Beating tissue, but no heart struc- } \\
\text { ture }\end{array}$ & 4. Very stunted, but axis discernible \\
\hline & 5. No discernible heart & 5. No axis discernible \\
\hline
\end{tabular}

accounted for without biasing the total severity-indices for terata. To test for differences in teratogenic response beween control(s) and treatment concentrations non-parametric Van der Waerden normal scores tests (SAS 1985a) and Van der Waerden posthoc multiple comparison procedures, $\alpha=0.05$ (Marascuilo \& McSweeney 1977) were then conducted using the total severity-indices

Categorical severity-indices. Analysis of individual response categories, CR, CV and SK (Table 1) was conducted as follows: for each embryo, the daily score for the CR index could range from 0 to 3 , for $\mathrm{CV} 0$ to 5 and for SK 0 to 5 . If an embryo died before the end of a test, a daily value of 4 was assigned to the CR index; the CV and SK indices were assigned a daily value of 6 . As with the total severity-index, assignment of values for embryo death in individual categories enabled us to account for mortalitites without introduction of bias, by mortalities of unknown cause.

Respective categonical indices were then analysed using the Van der Waerden normal scores test (SAS 1985a) and post-hoc multiple comparison procedures (Marascuilo \& McSweeney 1977).

Graphical presentation. Plots of combined embryo and larval survival, and standardized mean rank scores for terata, were generated to provide a visual overview of response trends. In each test, mean rank scores for terata were standardized by subtracting the lowest score for a control or exposure treatment from the remaining (higher) scores. Combined embryo and larval survival, and standardized mean rank scores, were plotted using Statistical Analysis System SAS/Graph Proc GCHART procedures (SAS 1985b).

\section{RESULTS}

Each of the test compounds (2,4-DNP, PW and NPH) was teratogenic. However, survival in control and exposed embryos and larvae was not significantly different in 5 of 6 tests; the only exception being the test with 2 - to 4 -cell embryos and 2,4-DNP $\left(\chi^{2}=16.23,4 \mathrm{df}\right)$.

Table 2. Menidia beryllina. Nominal and measured exposure concentrations of 2,4-DNP. Measured dissolved oxygen (DO) and $\mathrm{pH}$ values are also summarized

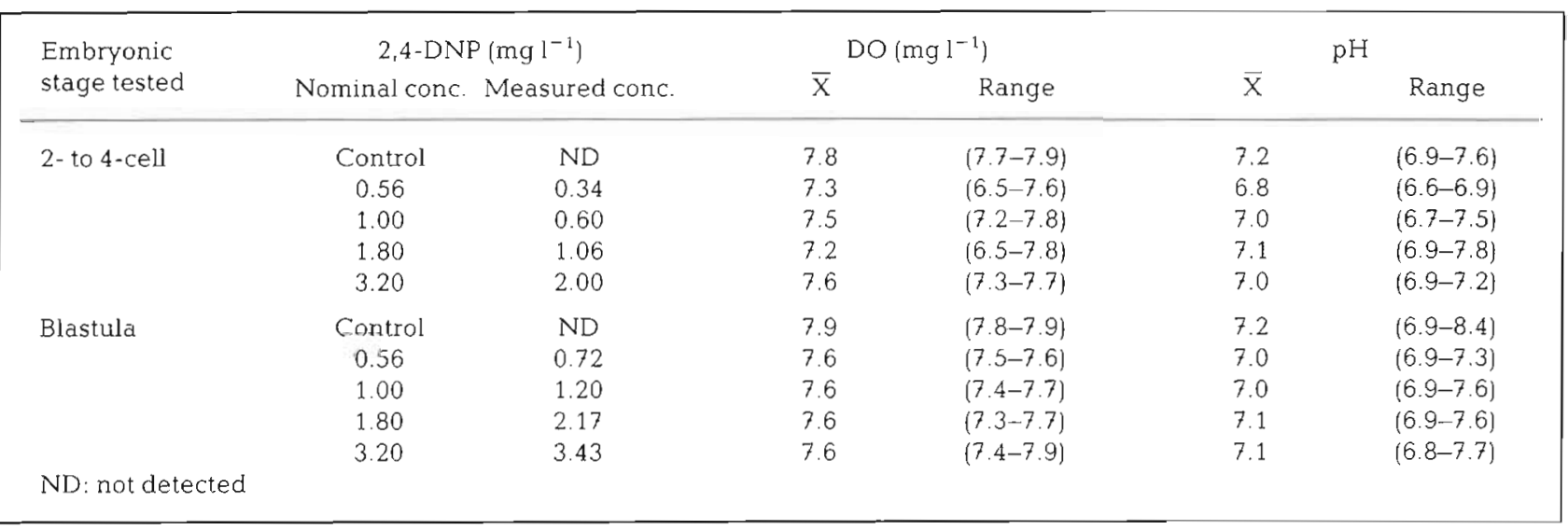




\section{2,4-DNP}

Nominal exposure concentrations of 2,4-DNP and measured amounts are summarized in Table 2. Also reported are final values for $\mathrm{DO}$ and $\mathrm{pH}$. An example of terata observed in embryos exposed to 2,4-DNP is shown in Fig. 1a. Teratogenic expressions included reductions in cephalization (head size), defects in cardiac structure and function including malformed valves, tube heart and reduced circulation; and mild scoliosis or lordosis with stunting of the skeletal axis.

The combined percentages for embryo and larval survival in tests begun with 2- to 4-cell and blastula stage embryos exposed to 2,4-DNP are summarized in Fig. 2a. Both control groups had 100\% embryo and larval survival. The percentages trended downward as nominal concentrations of 2,4-DNP increased from 0.56 to $3.2 \mathrm{mg} \mathrm{l}^{-1}$. At the 2 highest concentrations of 1.8 and

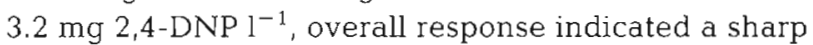
decline in embryo hatching, but not survival, for tests initiated with the 2-to 4 -cell stage. In comparison, tests started with blastula stage embryos yielded comparable overall survival but a much higher proportion of

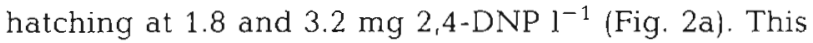
trend occurred even though measured exposure concentrations of 2,4-DNP were higher in tests begun with blastula stage embryos (Table 2).

The standardized mean rank scores, presented in Fig. 2b, provide an overview of teratological responses in embryos exposed to 2,4-DNP. The scores are a summation of craniofacial (CR), cardiovascular (CV) and skeletal (SK) indices. There was a marked increase in terata with increasing exposure concentration. The 2 highest nominal concentrations of 2,4-DNP demonstrated the strongest response (Fig. 2b). Post-hoc analyses comparing respective controls with each exposure concentration revealed statistically significant responses in CR, CV and SK indices at the 2 highest concentrations; the one exception being the SK index in the blastula stage at $1.8 \mathrm{mg} \mathrm{2,4-DNP} \mathrm{^{-1 }}$ (Table 3).

Table 3. Menidia beryllina. Post-hoc comparison of responses at 4 nominal concentrations of 2,4-DNP to controls in tests initiated with 2 - to 4 -cell and blastula stage embryos. CR: craniofacial; CV: cardiovascular; SK: skeletal index. NS: not statistically significant; S: statistically significant, $\alpha=0.05$

\begin{tabular}{|lrrrrrr}
\hline $\begin{array}{l}\text { 2,4-DNP } \\
\text { concentration } \\
\left(\mathrm{mg} \mathrm{l}^{-1}\right)\end{array}$ & \multicolumn{4}{c}{ Initial developmental stage } \\
2- to 4-cell & $\mathrm{CR}$ & $\mathrm{CV}$ & $\mathrm{SK}$ & $\mathrm{CR}$ & $\mathrm{CV}$ & $\mathrm{SK}$ \\
\hline 0.56 & $\mathrm{NS}$ & $\mathrm{NS}$ & $\mathrm{NS}$ & $\mathrm{NS}$ & $\mathrm{NS}$ & $\mathrm{NS}$ \\
1.00 & $\mathrm{NS}$ & $\mathrm{NS}$ & $\mathrm{NS}$ & $\mathrm{NS}$ & $\mathrm{NS}$ & $\mathrm{NS}$ \\
1.80 & $\mathrm{~S}$ & $\mathrm{~S}$ & $\mathrm{~S}$ & $\mathrm{~S}$ & $\mathrm{~S}$ & $\mathrm{NS}$ \\
3.20 & $\mathrm{~S}$ & $\mathrm{~S}$ & $\mathrm{~S}$ & $\mathrm{~S}$ & $\mathrm{~S}$ & $\mathrm{~S}$ \\
\hline
\end{tabular}

\section{Produced water}

Concentrations of identified components in the sample of PW tested are summarized in Table 4. Nominal exposure concentrations (\% PW) are summarized with

Table 4. Menidia beryllina. Chemical characerization of PW used in this study. Detection limits for individual non-volatile and volatile organics 10 to $50 \mu \mathrm{g} \mathrm{l}^{-1}$; metals 0.1 to $1000 \mathrm{\mu g} \mathrm{l}^{-1}$; other components 10 to $100 \mu \mathrm{g} \mathrm{l}^{-1}$

\begin{tabular}{|c|c|c|}
\hline $\begin{array}{l}\text { Compound } \\
\text { detected }\end{array}$ & $\begin{array}{l}\text { Analytical } \\
\text { procedure }\end{array}$ & $\begin{array}{c}\text { Measured } \\
\text { conc. }\left(\operatorname{ug~l}^{-1}\right)\end{array}$ \\
\hline 2- Propanone & A & 2101.7 \\
\hline Benzene & $\mathrm{A}$ & 3206.6 \\
\hline Methylene chloride & $\mathrm{A}$ & 132.5 \\
\hline 2-Butanone & $\mathrm{A}$ & 741.6 \\
\hline Naphthalene & $\mathrm{B}$ & 133.0 \\
\hline 2-Methylnaphthalene & $\mathrm{B}$ & 63.2 \\
\hline Biphenyl & $\mathrm{B}$ & 11.4 \\
\hline a-Cresol & $\mathrm{B}$ & 190.0 \\
\hline Ethylbenzene & A & 66.4 \\
\hline 2,4-Dimethylphenol & $\mathrm{B}$ & 366.4 \\
\hline$p$-Cresol & $\mathrm{B}$ & 809.8 \\
\hline 4-Methyl-2-pentanone & $\mathrm{B}$ & 29.8 \\
\hline Toluene & $\mathrm{A}$ & 1848.8 \\
\hline Phenol & $\mathrm{B}$ & 1510.3 \\
\hline n-Dodecane & $\mathrm{B}$ & 127.2 \\
\hline$n$-Eicosane & $\mathrm{B}$ & 98.9 \\
\hline$n$-Decane & $\mathrm{B}$ & 49.1 \\
\hline Hexanoic acid & $\mathrm{B}$ & 899.5 \\
\hline$n$-Hexadecane & $\mathrm{B}$ & 189.8 \\
\hline 2-Hexanone & $\mathrm{B}$ & 28.8 \\
\hline n-Octadecane & $\mathrm{B}$ & 93.6 \\
\hline$n$-Tetradecane & $\mathrm{B}$ & 84.3 \\
\hline$n$-Docosane & $\mathrm{B}$ & 64.9 \\
\hline$n$-Hexacosane & $\mathrm{B}$ & 46.2 \\
\hline$n$-Octacosane & $\mathrm{B}$ & 39.3 \\
\hline$n$-Tricontane & $B$ & 46.2 \\
\hline$n$-Tetracosane & $B$ & 58.9 \\
\hline Iron & $\mathrm{C}$ & 1090.0 \\
\hline Lithium & $\mathrm{D}$ & 2080.0 \\
\hline Magnesium & C & 80100.0 \\
\hline Potassium & C & 120000.0 \\
\hline Silicon & C & 29800.0 \\
\hline Strontium & $\mathrm{C}$ & 25000.0 \\
\hline Tin & C & 290.0 \\
\hline Arsenic & C & 404.0 \\
\hline Barium & C & 12000.0 \\
\hline Boron & C & 37000.0 \\
\hline Zinc & $\mathrm{C}$ & 90.0 \\
\hline Calcium & $\mathrm{C}$ & 468000.0 \\
\hline Ammonia & $\mathrm{D}$ & 19000.0 \\
\hline Sulfur & $\mathrm{E}$ & 12100.0 \\
\hline Fluoride & $\overline{\mathrm{D}}$ & 3300.0 \\
\hline Oil and grease & $\mathrm{D}$ & 17000.0 \\
\hline \multicolumn{3}{|c|}{$\begin{array}{l}\text { Analytical procedures as follows. A: US EPA Method } \\
1624 \text { C for volatile organics; B: US EPA Method } 1625 \mathrm{C} \text { for } \\
\text { non-volatitle organics; C: US EPA Methods } 200.7 \mathrm{M}, 204.2 \\
206.2,245.5,270.2,272.2,279.2,785 \text { and } 3020 \text { (Acid diges } \\
\text { tion) for metals; D: US EPA Methods } 160.1,160.2,160.3 \\
340.1,350.2,413.1 \text {; E: US EPA Methods-Super Scan (US } \\
\text { EPA. 1987) }\end{array}$} \\
\hline
\end{tabular}




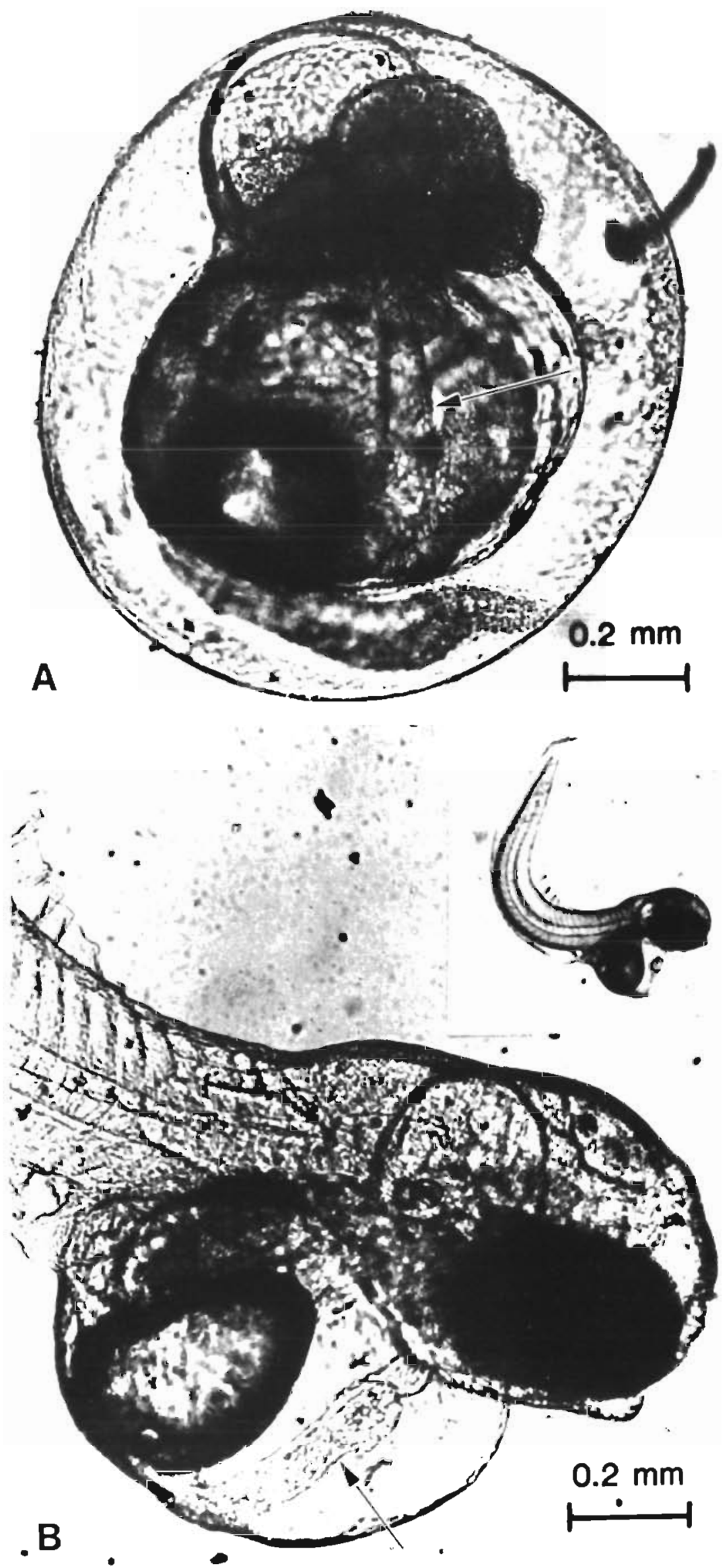

Fig. 1. Menidia beryllina. (A) Five d old embryo exposed to nominal 1.8 mg 2,4-DNP $1^{-1}$ from blastula stage, scored as CR 2, CV 2, SK 3 (refer to Table 1). (B) Hatched larvae exposed to $20 \%$ PW from 2- to 4-cell stage, scored as CR 1, CV 2, SK 2; note tube heart (arrow) and vertebral curvature (inset) 


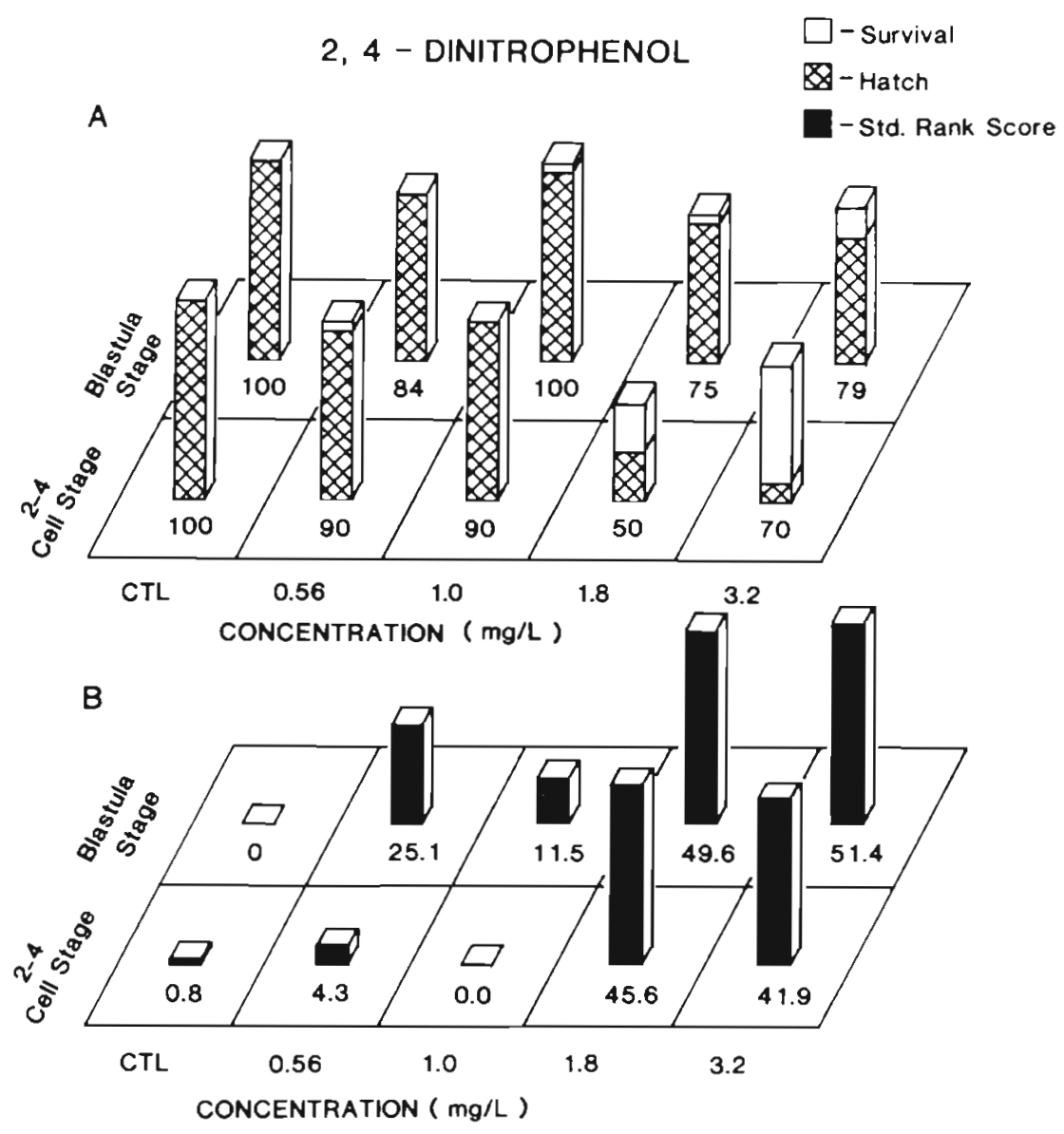

Fig. 2. Menidia beryllina. Results for tests initiated with 2- to 4-cell and blastula stage embryos exposed to 2,4-DNP for 7 to 8 d. (A) Combined percentage survival for control embryos and larvae, and teratogen-exposed individuals. (B) Standardized mean rank scores for combined teratological expressions in control and exposed embryos and larvae

respective final values for $\mathrm{DO}$ and $\mathrm{pH}$ (Table 5). Because the $1 \%$ PW solution had a salinity of $0.35 \%$ and the $20 \%$ PW solution a salinity of $7 \%, 2$ controls were maintained in each test: one at the lowest test salinity, a second at the highest salinity.

An example of terata observed in embryos exposed to PW is shown in Fig. 1b. Responses include moderate to severe reductions in cephalization, tube heart, and moderate to severe reductions in circulation including hemostasis, stunted axes, and lordosis, scoliosis, or kyphosis.

The combined percentages for embryo and larval survival in tests begun with 2- to 4 -cell and blastula stage embryos exposed to PW are summarized in Fig. 3 a. Control survival in tests begun with 2 - to 4 -cell embryos ranged from $74 \%$ (low salinity), to $95 \%$ (high salinity). Survival of embryos and larvae was similar to controls at each PW concentration. However, the $20 \%$ PW exposure caused a substantial reduction in the proportion of hatched larvae, but not embryo survival. A similar trend was observed in tests begun with blastula stage embryos (Fig. 3a).

The standardized mean rank scores presented in Fig. 3b summarize overall PW teratogenicity. The summary data show an increase in terata with increasing concentrations of PW. Post-hoc analyses compared both the low salinity and high salinity controls to terata in the 3 effect indices (CR, CV and SK). The 1 and $5 \%$ PW solutions did not result in responses significantly different from low or high salinity controls. However, exposure to the 10 and $20 \%$ PW solutions did produce significant responses in CR, CV and SK indices; depending on the developmental stage tested and whether comparisons were made to responses in low or high salinity controls (Table 6). While comparisons to both low and high salinity controls were made, it is apparent that 2- to 4-cell embryos exposed to 10 and $20 \%$ PW, and compared to the high salinity control, were more sensitive than blastula stage embryos exposed to similar PW concentrations (Table 6, bottom).

\section{Naphthalene}

Nominal exposure concentrations of NPH and measured amounts are summarized in Table 7 . Also reported are final values for $\mathrm{DO}$ and $\mathrm{pH}$ from individual tubes. 
Table 5. Menidia beryllina. Percentage PW exposures. Refer to Table 4 for list of individual components. Measured dissolved oxygen (DO) and $\mathrm{pH}$ values are also summarized

\begin{tabular}{|c|c|c|c|c|c|}
\hline \multirow{2}{*}{$\begin{array}{l}\text { Embryonic } \\
\text { stage tested }\end{array}$} & \multirow[t]{2}{*}{ PW conc. $(\%)$} & \multicolumn{2}{|c|}{$\mathrm{DO}\left(\mathrm{mg} \mathrm{l}^{-1}\right)$} & \multicolumn{2}{|c|}{$\mathrm{pH}$} \\
\hline & & $\overline{\mathrm{X}}$ & Range & $\overline{\mathrm{X}}$ & Range \\
\hline \multirow[t]{6}{*}{2 - to 4 -cell } & CTL (low sal.) & 7.8 & $(7.6-7.9)$ & 6.1 & $(5.7-6.9)$ \\
\hline & CTL (high sal.) & 7.1 & $(7.1-7.3)$ & 6.9 & $(6.8-7.0)$ \\
\hline & 1 & 7.6 & $(7.5-7.7)$ & 6.8 & $(6.8-6.9)$ \\
\hline & 5 & 7.3 & $(7.3-7.4)$ & 6.9 & $(6.8-7.0)$ \\
\hline & 10 & 7.0 & $(6.0-7.5)$ & 7.0 & $(6.9-7.0)$ \\
\hline & 20 & 6.7 & $(5.7-7.0)$ & 7.1 & $(7.0-7.1)$ \\
\hline \multirow[t]{6}{*}{ Blastula } & CTL (low sal.) & 8.0 & $(7.9-8.2)$ & 5.9 & $(5.7-6.1)$ \\
\hline & CTL (high sal.) & 7.5 & $(7.4-7.5)$ & 6.8 & $(6.6-6.8)$ \\
\hline & 1 & 7.9 & $(7.8-8.0)$ & 6.7 & $(6.6-6.8)$ \\
\hline & 5 & 7.7 & $(7.1-8.0)$ & 6.9 & $(6.9-6.9)$ \\
\hline & 10 & 7.6 & $(7.4-7.8)$ & 7.1 & $(7.0-7.1)$ \\
\hline & 20 & 7.4 & $(7.3-7.6)$ & 72 & $(71-7.2)$ \\
\hline
\end{tabular}

Responses were noted primarily in the cardiovascular system and included tube heart, reduced circulation or hemostasis, and stunted axes. The combined percentages for embryo and larval survival in tests begun with 2- to 4 -cell and blastula stage embryos, exposed to NPH, are summarized in Fig. 4 a. Both control groups had $95 \%$ combined survival. The combined percentages were also high at all NPH exposure concentrations. Although very few of the 2-to 4-cell and blastula stage embryos exposed to $10 \mathrm{mg} \mathrm{NPH}^{-1}$ hatched, nearly all embryos survived the 7 to $8 \mathrm{~d}$ test (Fig. $4 \mathrm{a}$ ).

The standardized mean rank scores presented in Fig. $4 \mathrm{~b}$ show a trend of increased teratological expression with increasing NPH concentrations. Exposure to nom-

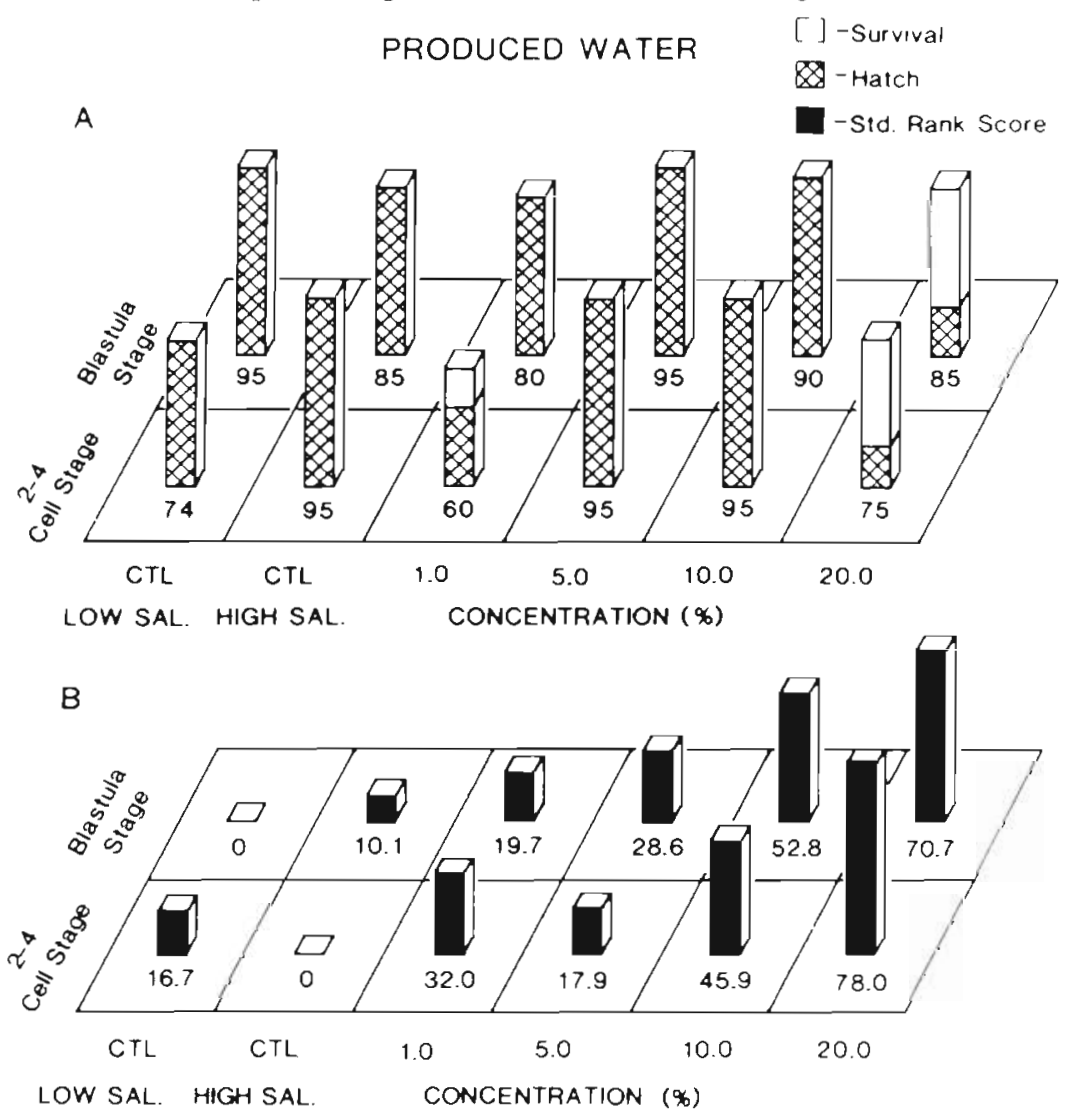

Fig. 3. Menidia beryllina. Results for tests initiated with 2- to 4-cell and blastula stage embryos exposed to PW for 7 to $8 \mathrm{~d}$ (A) Combined percentage survival for control embryos and larvae; and teratogen-exposed individuals. (B) Standardized mean rank socres for teratological expressions in control and exposed embryos and larvae 
Table 6. Menidia beryllina. Post-hoc comparison of responses at 4 nominal concentrations of PW to low salinity (top) and high salinity (bottom) controls. Tests were initiated with 2- to 4-cell and blastula stage embryos. CR: craniofacial; CV: cardiovascular; SK: skeletal index. NS: not significantly different; $S$ : statistically significant, $\alpha=0.05$

\begin{tabular}{|c|c|c|c|c|c|c|c|}
\hline \multirow{3}{*}{$\begin{array}{l}\text { 'Produced water' } \\
\text { concentration } \\
\text { percentage }\end{array}$} & \multirow[t]{3}{*}{ Sal. $(\% 0)$} & \multicolumn{6}{|c|}{ Initial developmental stage } \\
\hline & & & to $4-c$ & & & Blastul & \\
\hline & & CR & $\mathrm{CV}$ & SK & CR & $\mathrm{CV}$ & SK \\
\hline 1.0 & 0.35 & NS & NS & NS & NS & NS & NS \\
\hline 5.0 & 1.75 & NS & NS & NS & NS & NS & NS \\
\hline 10.0 & 3.50 & NS & NS & NS & S & $\mathrm{S}$ & $\mathrm{S}$ \\
\hline 20.0 & 7.00 & $\mathrm{~S}$ & $\mathrm{~S}$ & S & S & $S$ & S \\
\hline 1.0 & 0.35 & NS & NS & NS & NS & NS & NS \\
\hline 5.0 & 1.75 & NS & NS & NS & NS & NS & NS \\
\hline 10.0 & 3.50 & $\mathrm{~S}$ & $\mathrm{~S}$ & NS & $\mathrm{s}$ & NS & NS \\
\hline 20.0 & 7.00 & $\mathrm{~S}$ & $\mathrm{~S}$ & $\mathrm{~s}$ & $\mathrm{~S}$ & $\mathrm{~S}$ & $\mathrm{~S}$ \\
\hline
\end{tabular}

Table 7. Menidia beryllina. Nominal and measured exposure concentrations of naphthalene. Measured dissolved oxygen (DO) and $\mathrm{pH}$ values are also summarized

\begin{tabular}{|c|c|c|c|c|c|c|}
\hline \multirow{2}{*}{$\begin{array}{l}\text { Embryonic } \\
\text { stage tested }\end{array}$} & \multicolumn{2}{|c|}{ Naphthalene $\left(\mathrm{mg} \mathrm{l}^{-1}\right.$ ) } & \multicolumn{2}{|c|}{$\mathrm{DO}\left(\mathrm{mg} \mathrm{l}^{-1}\right)$} & \multicolumn{2}{|c|}{$\mathrm{pH}$} \\
\hline & Nominal conc. & Measured conc. & $\overline{\mathrm{x}}$ & Range & $\overline{\mathrm{x}}$ & Range \\
\hline \multirow[t]{5}{*}{ 2- to 4 -cell } & Control & ND & 7.7 & $(7.6-7.7)$ & 6.9 & $(6.8-7.1)$ \\
\hline & 1.8 & ND & 7.6 & $(7.4-7.7)$ & 6.6 & $(6.6-6.7)$ \\
\hline & 3.2 & 0.55 & 7.6 & $(7.4-7.8)$ & 6.6 & $(6.5-6.7)$ \\
\hline & 5.6 & 2.35 & 7.7 & $(7.6-7.9)$ & 6.7 & $(6.6-6.8)$ \\
\hline & 10.0 & 4.95 & 7.7 & $(7.6-7.8)$ & 6.7 & $(6.3-6.9)$ \\
\hline \multirow[t]{5}{*}{ Blastula } & Control & ND & 7.8 & $(7.6-7.9)$ & 6.7 & $(6.6-6.9)$ \\
\hline & 1.8 & ND & 7.7 & $(7.6-7.8)$ & 6.6 & $(6.6-6.7)$ \\
\hline & 3.2 & 0.60 & 7.7 & $(7.6-7.9)$ & 6.6 & $(6.5-6.7)$ \\
\hline & 5.6 & 2.15 & 7.6 & $(7.4-7.9)$ & 6.5 & $(6.4-6.7)$ \\
\hline & 10.0 & 6.50 & 7.7 & $(7.7-7.8)$ & 6.8 & $(6.5-7.0)$ \\
\hline
\end{tabular}

Table 8. Menidia beryllina. Post-hoc comparison of responses at 4 nominal concentrations of NPH to controls in tests initiated with 2 - to 4 -cell and blastula stage embryos. CR: craniofacial; CV: cardiovascular; SK: skeletal index. NS: not significant; S: statistically significant, $\alpha=0.05$

\begin{tabular}{|crrrrrr|}
\hline $\begin{array}{l}\text { Naphthalene } \\
\text { concentration } \\
\left(\mathrm{mg} \mathrm{l}^{-1}\right)\end{array}$ & \multicolumn{4}{c}{ Initial developmental stage } \\
& 2- to 4-cell & \multicolumn{3}{c|}{ Blastula } \\
& $\mathrm{CR}$ & $\mathrm{CV}$ & $\mathrm{SK}$ & $\mathrm{CR}$ & $\mathrm{CV}$ & $\mathrm{SK}$ \\
\hline 1.8 & $\mathrm{NS}$ & $\mathrm{NS}$ & $\mathrm{NS}$ & $\mathrm{NS}$ & $\mathrm{NS}$ & $\mathrm{NS}$ \\
3.2 & $\mathrm{NS}$ & $\mathrm{S}$ & $\mathrm{NS}$ & $\mathrm{NS}$ & $\mathrm{NS}$ & $\mathrm{NS}$ \\
5.6 & $\mathrm{~S}$ & $\mathrm{~S}$ & $\mathrm{~S}$ & $\mathrm{NS}$ & $\mathrm{NS}$ & $\mathrm{S}$ \\
10.0 & $\mathrm{~S}$ & $\mathrm{~S}$ & $\mathrm{~S}$ & $\mathrm{~S}$ & $\mathrm{~S}$ & $\mathrm{~S}$ \\
\hline
\end{tabular}

inal concentrations of 5.6 and $10 \mathrm{mg} \mathrm{NPH} 1^{-1}$ caused marked increases in rank scores for terata, indicating that 2- to 4-cell embryos may have been more sensitive than the blastula stage (Fig. 4b). Post-hoc analyses revealed statistically significant responses in the $C R$, CV and SK indices at the 2 highest exposure concen- trations for tests begun with 2- to 4-cell embryos. The blastula stage was less responsive (Table 8 ).

\section{DISCUSSION}

There are several advantages in testing developmental effects of toxicants in aquatic species. The organisms are less costly to obtain and maintain, the embryonic period is usually shorter than in mammals and direct observation of developing embryos is possible (Weis \& Weis 1987).

Each environmental contaminant tested in this study was teratogenic to Menidia beryllina embryos. In general, combined embryo and larval survival in respective tests was similar to controls, even at the highest toxicant concentrations, indicating that 2,4-DNP, PW and NPH were not lethal, but teratogenic.

Responses of Menidia beryllina embryos to 2,4-DNP were characterized by reductions in cephalization 


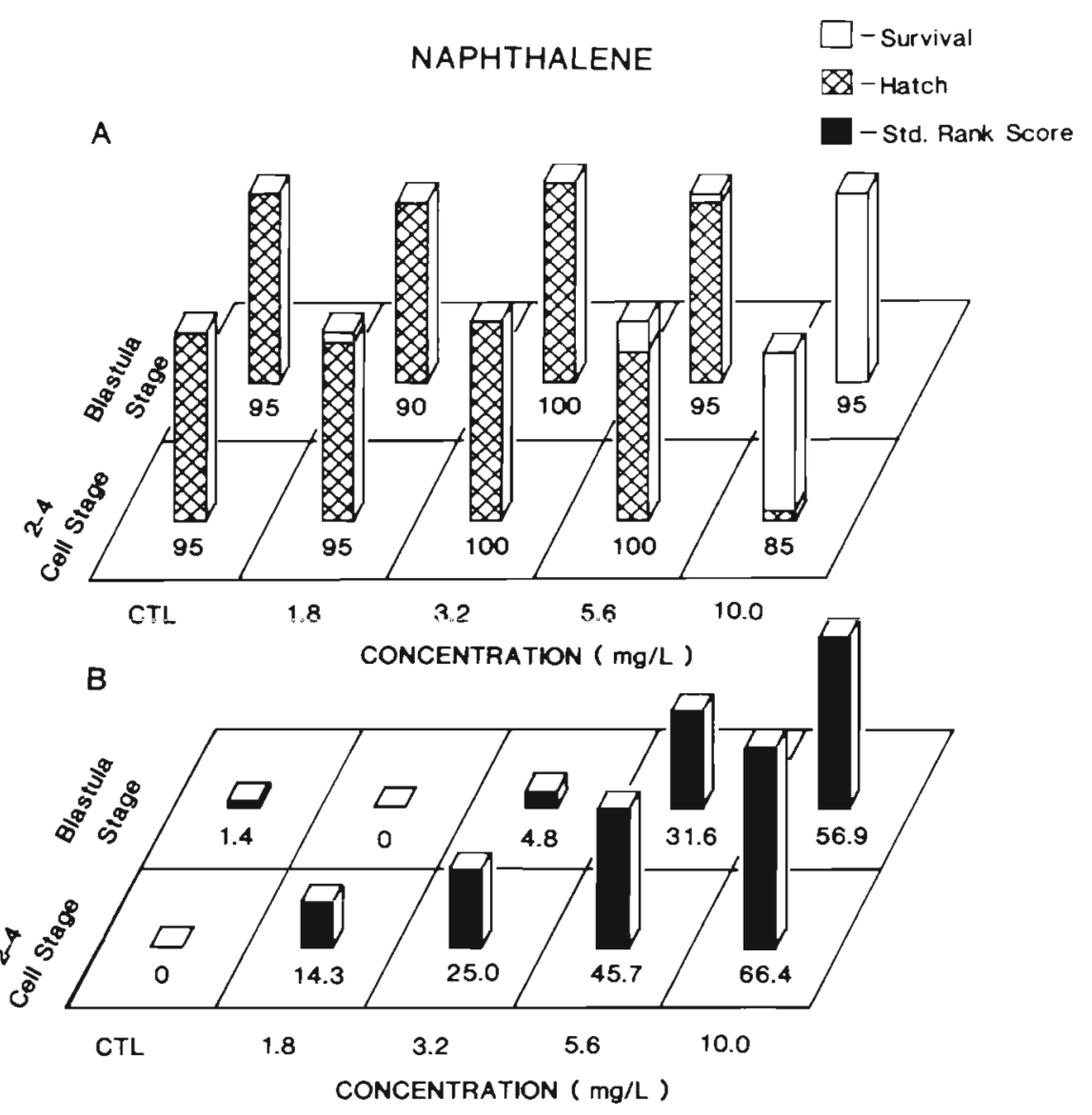

Fig. 4. Menidia beryllina. Results for tests initiated with 2- to 4 -cell and blastula stage embryos exposed to NPH for 7 to $8 \mathrm{~d}$. (A) Combined percentage survival for control embryos and larvae, and teratogen-exposed individuals. (B) Standardized mean rank scores for teratological expressions in control and exposed embryos and larvae

(head size), slight defects in heart structure including reduced circulation, and mild scoliosis or lordosis with some stunting of the skeletal axis (Fig. 1a). A similar response was noted by Waterman (1939) who exposed late cleavage embryos of medaka Oryzias latipes to 2,4-DNP concentrations ranging from 8.3 to $25 \mathrm{mg} \mathrm{l}^{-1}$. Abnormalities in the heart and extra embryonic vascular system were observed. Deformities and reductions in the myotomes were also common, generally reflected in shortening and curious shapes and positions of the tail.

Exposure of herring Clupea harengus embryos to 2,4- and 2,5-DNP at concentration of 0.005 to $0.1 \mathrm{mmol}$ $\mathrm{l}^{-1}\left(0.93\right.$ to $\left.18.4 \mathrm{mg} \mathrm{l}^{-1}\right)$ also produced various malformations including anophthalmy, symmetrical and microphthalmy, curled bodies and dedifferentiation. Exposure to 2,4-DNP started with 48 h old embryos resulted in a higher proportion of abnormalities than exposures started with 55 h old embryos (Rosenthal \& Stelzer 1970). A similar age-dependent sensitivity to 2,4-DNP was noted in rainbow trout Salmo irideus embryos. The maximum exposure time, after which some eggs continue to develop, increased from $8.5 \mathrm{~h}$ for 8-cell embryos to $72 \mathrm{~h}$ for blastula stage embryos (DeVillers \& Chanconie 1972). The response of Menidia beryllina embryos to 2,4-DNP also appears to be age dependent. At the higher exposure concentrations, there was a lower proportion of hatching for 2 to 4-cell embryos than blastula stage individuals. Control hatching in these groups was identical at $100 \%$.

2,4-DNP has been shown to be a true uncoupling reagent, which inhibits the phosphorylation of ADP. Exposure of Clupea harengus embryos to $0.1 \mathrm{mmol} \mathrm{I}^{-1}$ 2,4-DNP (18.4 $\mathrm{mg} \mathrm{l}^{-1}$ ) caused an increase in respiration ranging from 30 to $400 \%$ above controls. Under the influence of 2,4-DNP, embryos metabolised more carbohydrate in $1 \mathrm{~d}$ than during the entire normal developmental period. The changeover to increased decomposition of carbohydrates was explained as a dislocation of energetic sources from the normal respiration process to glycolytic phosphorylation (Rosenthal \& Stelzer 1970. Stelzer et al. 1971). Bodine \& Boell (1938) suggested that the toxic effect of 2,4-DNP may be due to an accumulation of toxic metabolic products within the organism. 
The 'produced water' used in this study contains many of the components that comprise the watersoluble fraction (WSF) of crude oil (Kuhnhold 1974, Kuhnhold \& Busch 1978, MacLeod et al. 1978). The histopathology, teratogenicity, and toxicity of the WSF of crude oil has been studied in a variety of fish embryos and larvae (Linden et al. 1980, Stoss \& Haines 1979, Reichert \& Varanasi 1982).

Exposure of Menidia beryllina embryos to 10 and $20 \%$ PW resulted in a high rank score for terata. Responses included moderate to severe reduction in cephalization, tube hearts lacking normal chambering, morphology and/or pumping capacity, reduced circulation or hemostasis, and stunted axes.

In tests with adult Menidia beryllina, Solanzi \& Overstreet (1982) observed approximately $50 \%$ mortality after exposure to 5 or $50 \%$ WSF of southern Louisiana crude oil for $27 \mathrm{~d}$. Total measured hydrocarbons were 2.49 and $2.75 \mathrm{ppm}$, respectively. Histopathological changes included epithelial hyperplasia and fusion of gill lamellae, separation of respiratory epithelium from underlying tissue, necrosis of both neurosensory and sustentacular cells of olfactory lamellae and sustentacular epithelium, extensive lipid vacuolation in hepatocytes, and atrophy and necrosis of intrahepatic exocrine pancreatic nodules. The pancreas serve as the most specific pathological indicator of oil pollution.

Exposure of early stage embryos of Pacific herring Clupea harengus pallasi to the WSF of Prudhoe Bay crude oil at an initial concentration of $<1 \mu \mathrm{g} \mathrm{g}^{-1}$ water (measured concentration after $48 \mathrm{~h}$ was $0.68 \mu \mathrm{g}$ total hydrocarbons $\mathrm{g}^{-1}$ water) led to a statistically significant increase in larval abnormalities such as reduced cephalization, stunted bodies, or bent backs in an $L, S$ or helical configuration. Enlarged pericardial cavities were also recognized. Scanning electron microscopy of larvae provided evidence of pectoral fin exosion, a misfit of the lower jaw into the upper and a missing premaxillary bone. Branchiostegal membranes were also absent (Smith \& Cameron 1979). Exposure of older embryos, late neurula stage, for 4 to $144 \mathrm{~h}$ yielded no gross abnormalities in larvae. However, transmission electron microscopy did reveal inter- and intracellular spaces in brain and muscle tissue of exposed fish, but not controls. Many mitochondria in the body muscle of exposed specimens were swollen, some with deteriorating cristae structure (Cameron \& Smith 1980).

The acute toxicity of PW from the Buccaneer Field offshore production wells approximately $60 \mathrm{~km} \mathrm{SSW} \mathrm{of}$ Galveston Island, Texas, USA, was studied by Gallaway et al. (1981). They computed $96 \mathrm{~h} \mathrm{LC}_{50}$ values of between $0.95 \%$ PW for larvae and $11.6 \%$ PW for adult brown shrimp Penaeus aztecus. The single reported value for a fish, the crested blenny Hypleurochilus geminatus, was $26.9 \%$ PW. Rose \& Ward (1981) reported $96 \mathrm{~h} \mathrm{LD}_{50}$ values ranging from 0.7 to $40.8 \%$ PW in tests conducted with crested blennies and water from the Buccaneer Field. Median lethal responses of crested blennies of $0.7,26.9$ and $40.8 \%$ PW compare favorably to statistically significant increases in terata for Menidia beryllina embryos exposed to 10 and $20 \%$ PW.

Exposure of Menidia beryllina embryos to nominal concentrations of 5.6 and $10 \mathrm{mg} \mathrm{NPH} \mathrm{l}^{-1}$ resulted in moderate to severe reductions in cephalization, slight defects in heart structure and reduced circulation; or tube hearts without chambers or valves, and greatly reduced circulation or hemostasis. Skeletal expressions included scoliosis and stunting.

Kuhnhold \& Busch (1978) reported on the penetration of hydrocarbons into salmon Salmo salar embryos. After 3 d exposure, penetration was $98 \%$ for naphthalene, $90 \%$ for benzopyrene, and $52 \%$ for hexadecane. Solbakken et al. (1984) also observed rapid accumulation of naphthalene and phenanthrene in Atlantic cod Gadus morhua eggs; followed by rapid loss when exposures ended. Resistance of fish embryos to 2-methylnaphthalene (2-MN) was studied by Stene \& Lonning (1984). They observed that chorion thickness, which may have retarded 2-MN penetration, volume of perivitelline space and percentage lipid in eggs had an influence on susceptibility. Lumpsucker Cyclopteus lumpus embryos with a chorion thickness of $60 \mu \mathrm{m}$ and dry weight lipid content of 21 to $26 \%$

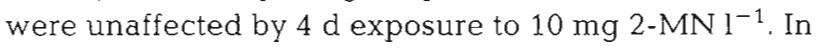
contrast, embryos of the long rough dab Hippoglossoides platessoides (chorion thickness $2.5 \mu \mathrm{m}$, lipid 11 to $13 \%$ ), were highly susceptible with no normal

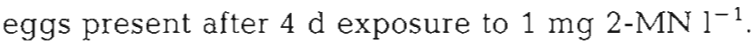

Sharp et al. (1979) reported a decrease in permeability of the chorionic membrane to NPH during development of Fundulus heteroclitus eggs. In Menidia

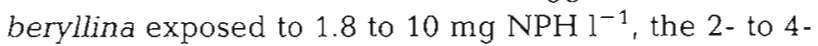
cell stage demonstrated higher mean rank scores for terata than the blastula stage. Higher scores could indicate increased chorionic permeability in recently fertilized 2- to 4-cell embryos or perhaps the effect of longer exposure to NPH. Saethre et al. (1984) also studied the effect of NPH, 1 - and 2-MN, and dimethylnaphthalenes on Atlantic cod Gadus morhua embryos and suggested changes in permeability and structure of the egg membranes. A similar phenomenon was noted in cell walls of Chlamydomonas angulosa exposed to hydrocarbons (Soto et al. 1979).

Our results with Menidia beryllina embryos exposed to 2,4-DNP are similar to responses reported for other freshwater and marine fish embryos. The teratogenic responses in $M$. beryllina embryos exposed to PW and one of its constituents, NPH, are cause for concern. Discharge of hydrocarbon-laden saline waters, which 
may also contain substantial quantities of heavy metals, into biologically productive near-shore or semienclosed estuarine habitats (Biglane \& LaFleur 1967. Gunter 1967) is a potential environmental hazard that may require additional study.

Acknowledgements. We thank Drs D. E. Hinton and J. S. Weis for reviewing an early version of the manuscript; and L. L Hale for preparing the figures.

\section{LITERATURE CITED}

Biglane, K. E., LaFleur, R. A. (1967). Notes on estuarine pollution with emphasis on the Louisiana Gulf Coast. In Lauff, G. H. (ed.) Estuaries. Publs Am. Ass. Advmt Sci. Washington, D. C., p. 690-692

Bodine, J. H., Boell, E. J. (1938). The influence of some dinitrophenols or respiratory metabolism during certain phases of embryonic development. J. cell. comp. Physiol 11: $41-64$

Devillers, M. C., Chanconie, M. (1972). Action du 2-4 dinitrophenol sur la segmentation de l'oeuf de truite (Salmo irideus Gib.) Acta Embryol. Morph. exp. 1972: 279-288

Cameron, J. A., Smith, R. L. (1980). Ultrastructural effects of crude oil on early life stages of Pacific Herring. Trans. Am Fish. Soc. 109: 224-228

Farm Chemicals Handbook (1986). 72nd ed, Meister Publishing Co., Willoughby, Ohio, p. C 85

Gallaway, B. J., Martin, L. R., Howard, R. L., Boland, G. S., Dennis, G. D. (1981). Effects on artificial reef and demersal fish and macrocrustacean communities. In: Middleditch, B. S. (ed.) Environmental effects of offshore soil production the Buccaneer gas and oil field study. Plenum Press, New York, p. 237-299

Gunter, G. (1967). Some relationships of estuaries to the fisheries of the Gulf of Mexico. In: Lauff, G. H. (ed.) Estuaries. Am. Assoc. Adv. Science, Washington, D. C., p. $621-638$

Kuhnhold, W. W. (1974). Investigations on the toxicity of seawater extracts of three crude oils on eggs of cod (Gadus morhua L.) Ber. dt. wiss. Kommn. Meeresforsch. 23: $165-180$

Kuhnhold, W W., Busch, F. (1978). On the uptake of three different types of hydrocarbons by salmon eggs (Salmo salar L.). Ber. dt. wiss. Kommn Meeresforsch. 26: 50-59

Lagler, K. F., Bardach, J. E., Miller, R. R., Passino, D. R. (1977). Ichthyology. 2nd edn. John. Wiley and Sons, New York

Linden, O., Laughlin, R., Sharp, J. R., Neff, J. M. (1980). The combined effect of salinity, temperature and oil on the growth pattern of embryos of the killifish. Fundulus heteroclitus, Walbaum. Mar, environ. Research. 3: $129-144$

Macleod, W. D., Jr., Thomas, L. C., Uyeda, M. Y., Jenkins, R. G. (1978). Evidence of Argo Merchant oil in marine biota by glass capillary GC analysis. Proceeding-Conference on Assessment of Ecological Impacts of Oil Spills. Am. Inst. of Biol. Sciences, Keystone, Colorado, p. 138-179

Marascuilo, L. A., McSweeney, M. (1977). Nonparametric and distribution-free methods for the social sciences. Brooks/ Cole, Monterey, Califormia

Middaugh, D. P., Hemmer, M. J. (1984). Spawning of the tidewater silverside, Menidia peninsulae (Goode and Bean) in response to tidal and lighting schedules in the laboratory. Estuaries 7: 137-146
Middaugh, D. P., Hemmer, M. J., Rose, Y. L. (1986). Laboratory spawning cues in Menidia beryllina and Menidia peninsulae (Pisces: Atherinidae) with notes on survival and growth of larvae at different salinities. Environ. Biol. Fish 18(2): 107-117

Middleditch, B. S. (1981). Hydrocarbons and sulfur. In: Middleditch, B. S. (ed.) Enrivonmental effects of offshore oil production - the Buccaneer gas and oil field study. Plenum Press, New York, p. 15-54

Middleditch, B. S. (1984). Ecological effects of produced water effluents from offshore oil and gas production platforms. Ocean Science 9: 191-316

Reichert, W. L., Varanasi, U. (1982). Metabolism of orally administered naphthalene in spawning English sole (Parophrys vetulus). Environ. Res. 27: 316-324

Rosenthal, H., Stelzer, R. (1970). Wirkungen von 2,4- und 2,5dinitrophenol auf die Embryonalentwicklung des Herings, Clupea harengus. Mar. Biol. 5: 325-336

Rose, C. D., Ward. T J. (1981). Acute toxicity and aquatic hazard associated with discharge formation water. In: Middleditch, B. S. (ed.) Environmental effects of offshore oil production - the Buccaneer gas and oil field study. Plenum Press, New York, p. 301-324

SAS Institute Inc. (1985a). SAS user's guide: statistics, Version 5 edn. Cary, North Carolina

SAS Institute Inc. (1985b). SAS/graph user's guide, Version 5 edn. Cary, North Carolina

Saethre, L. J., Falk-Petersen, I. B., Syndes, L. K., Lonning, S., Naley, A. M. (1984). Toxicity and chemical reactivity of naphthalene and methylnaphthalenes. Aquat. Toxicol. 5: 291-306

Sharp, J. R., Fucik, K. W., Neff, J. M. (1979). Physiological basis of differential sensitivity of fish embryonic stages of oil pollution. In: Vemberg, F. J., Vernberg, W B., Calabrese, A. (eds.) Marine pollution: functional processes. Academic Press, New York, p. 85-108

Smith, R. L., Cameron, J. A. (1979). Effect of water soluble fraction of Prudhoe Bay crude oil on embryonic development of Pacific herring. Trans. Am. Fish. Soc. 108: 70-75

Solanzi, M. A., Overstreet, R. M. (1982). Histological changes in two estuarine fishes, Menidia beryllina (Cope) and Trinectes maculatus (Bloch and Schneider) exposed to crude oil and its water-soluble fractions. J. Fish Dis. 5: 13-35

Solbakken, J. E., Tilseth, S., PaImork, K. H. (1984). Uptake and elimination of aromatic hydrocarbons and a chlorinated biphenyl in eggs and larvae of cod Gadus morhua. Mar. Ecol. Prog. Ser. 16: 297-301

Soto, C., Hellebust, J. A., Hutchinson, T. C., Sheath, R. G. (1979). The effect of the hydrocarbon naphthalene on the morphology of the green flagellate, Chlamydomonas angulosa. Can. J. Bot. 57: 2729-2739

Stene, A., Lonning, S. (1984). Effects of 2-methylnaphthalene on eggs and larval of six marine fish species. Sarsia 69 : 199-203

Stelzer, R., Rosenthal, H., Siebers, D. (1971). Einfluß von 2,4 dinitrophenol auf die Atmung und die Konzentration einiger Metabolite bei Embryonen des Herings. Clupea harengus. Mar. Biol. 11: 369-378

Stoss, F. W. Haines, T A. (1979). The effects of toluene on embryos and fry of the Japanese medaka, Oryzias latipes, with a proposal for rapid determination of maximum acceptable toxicant concentration. Environ. Pollut. 13 $139-148$

US Environmental Protection Agency (1987). Technical report: Appendix D - Exploration, development, and production of crude oil and natural gas - Analytical methods U S. EPA 530-SW-87-005. Office of Water Regulation and 
Standards (WH-552) and Office of Solid Waste and Emergency Response, Washington, D. C.

Waterman, A. J. (1939). Effects of 2,4-dinitropenol on the early development of the teleost, Oryzias latipes. Biol. Bull. mar. biol. Lab. Woods Hole 76: 162-170

Weis, J. S., Weis, P. (1977). Effects of heavy metals on development of the killifish, Fundulus heteroclitus. J. Fish Biol. 11. $49-54$

Weis, J. S., Weis, P., Ricci, J. L. (1981). Effects of cadmium, zinc, salinity, and temperature on the teratogenicity of methylmercury to the killifish, Fundulus heteroclitus. Rapp. P.-v. Réun. Cons. int. Explor Mer 178: 64-70

Weis, P., Weis, J. S. (1982). Toxicity of methylmercury, mercuric chloride, and lead in killifish, Fundulus heteroclitus, from Southampton, New York. Environ. Res, 28: 364-374

Weis, J. S., Weis, P. (1987). Pollutants as developmental toxicants in aquatic organisms. Environ. Hlth Perspect. 71 : $77-85$

Responsible Subject Editor: Dr G. Peters; accepted for printing on December 28, 1987 